Khazanah: Jurnal Studi Islam dan Humaniora

ISSN: 0215-837X (p); 2460-7606 (e), Vol. 17 (2), 2019, pp. 227-244

DOI: $10.18592 /$ khazanah.v17i2.3216

Submit : 15/08/2019 Review : 25/09/2019 Publish : 31/12/2019

\title{
MEMOTRET WAJAH ISLAM MELALUI PERGURUAN TINGGI KEAGAMAAN ISLAM NEGERI DI INDONESIA
}

\author{
Hasbiyallah; Moh. Sulhan; Heri Khoiruddin; Undang Burhanudin \\ Universitas Islam Negeri Sunan Gunung Djati Bandung \\ hasbiyallah@uinsgd.ac.id
}

\begin{abstract}
Abstrack: This article aims to analyze living socialphenomena, important study material that becomes an academic attraction, especially when religion is faced with social change and actual problems that must be answered by Islam. PTKIN as a study institution of Islamic education today has received a response from the wider community and has become an interesting social phenomenon to study. The fundamental problem that is the focus of this study relates to the dynamics of the face of Islamic State Islamic Higher Education (PTKIN) in the context of change to the State Islamic University, especially with the inclusion of lecturers from various educational backgrounds, disciplines and diversity of organizations that become new forces at the State Islamic University (UIN). The focus of this study is interesting to study related to the religious views of UIN lecturers which are limited to lecturers who teach religious material in the study area outside the religious groups at three State Islamic Universities (UIN), namely UIN ArRaniry Aceh, UIN Sunan Kalijaga Yogyakarta, and UIN Sunan Gunung Djati Bandung. This research is a field research using qualitative methods. To obtain data is done by observation, interviews and documentation. The findings can be concluded that each State Islamic University (UIN) bas its own focus and specificity to appear and contribute to developing Islam Rahmatan Lil amin alamin by striving to formalize Islam and revive the Shari'a. Islamic portraits and religious views of the lecturers strongly agree that PTKIN supports the development of Islam which is rabmatan lil alamin and unites the differences of religion and ethnicity.
\end{abstract}

Keywords: Dynamics; Islamic Studies; Challenge; PTKIN; Dismution Era

\begin{abstract}
Abstrak: Artikel ini bertujuan untuk menganalisis fenomena sosial yang hidup, bahan studi penting yang menjadi daya tarik akademik, kbususnya ketika agama berbadapan dengan perubahan sosial dan masalah aktual yang harus dijawab oleh Islam. PTKIN sebagai lembaga studi pendidikan Islam dewasa ini telah mendapat respon masyarakat luas dan menjadi fenomena sosial yang menarik untuk diteliti. Masalah mendasar yang menjadi fokus penelitian ini terkait bagaimana dinamika wajah keislaman Perguruan Tinggi Keagamaan Islam Negeri (PTKIN) dalam konteks perubahan ke Universitas Islam Negeri terutama dengan masuknya tenaga dosen dari beragam latar belakang pendidikan, disiplin dan keragaman organisasi yang menjadi kekuatan baru di Universitas Islam Negeri (UIN). Fokus penelitian ini menarik untuk diteliti terkait pandangan keagamaan dosen UIN yang dibatasi pada para dosen yang mengajar materi keagamaan pada area studi di luar rumpun agama yang terdapat pada tiga Universitas Islam Negeri (UIN), yaitu UIN Ar-Raniry Aceh, UIN Sunan Kalijaga Yogyakarta, dan UIN Sunan Gunung Djati Bandung. Penelitian ini merupakan penelitian lapangan dengan menggunakan metode kualitatif. Untuk memperoleh data dilakukan dengan observasi, wawancara dan dokumentasi. Hasil temuan dapat disimpulkan bahwa masing- masing Universitas Islam Negeri (UIN) memiliki fokus dan kekbhususan tersendiri untuk tampil dan berkontribusi mengembangkan Islam Rahmatan Lil 'alamin dengan berupaya untuk. menformalkan Islam dan menghidupkan syariat. Potret Islam dan pandangan keagamaan dosen sangat setuju bahwa PTKIN menunjang pengembangan Islam yang rahmatan lil alamin dan menyatukan perbedaan agama dan suku bangsa.
\end{abstract}

Kata kunci: Dinamika; Studi Islam; Tantangan; PTKIN; Era Disrupsi 
Hasbiyallah, Moh. Sulhan, Heri Khoiruddin \& Undang Burhanudin

\section{Pendahuluan}

Islam merupakan fenomena sosial yang hidup, bahan studi penting yang menjadi daya tarik akademik, khususnya ketika agama berhadapan dengan perubahan sosial dan masalah aktual yang harus dijawab oleh Islam. ${ }^{1}$ Islam sebagai agama sebenarnya sudah menjadi sasaran studi tidak saja oleh kalangan muslim tetapi juga oleh non-muslim untuk tujuan dan kepentingan yang beragam dengan beragam pendekatan. ${ }^{2}$ Studi Keislaman Indonesia yang dilakukan oleh para Sarjana Belanda dan para orientalis banyak dimaksudkan untuk tujuan politik dan kebijakan terkait nasib warga bumi putera yang mayoritas Muslim. ${ }^{3}$ Woodward mengungkapkan bahwa islamisasi atau studi-studi di Indonesia merupakan produk dari kesadaran keislaman yang meningkat di kalangan rakyat Indonesia dan perubahan besar di kalangan para sarjana yang mendefinisikan diri mereka sebagai islamis. ${ }^{4}$

Dalam beberapa dasawarsa terakhir studi Islam Indonesia disinggung John Esposito terlalu elitis, ${ }^{5}$ yaitu studi Islam menjadi sebuah disiplin yang konservatif dan berorientasi filologis. Bahkan pada beberapa islamis tradisional memandang bahwa penerbitan edisi kritis dari sebuah teks klasik lebih tinggi nilainya dibandingkan dengan terjemahan atau analisis tematis. Mark R. Woodward juga secara kritis menilai bahwa studi kritis memang memainkan peran penting dalam kesarjanaan yang berorientasi pada teks, namun teks-teks itu sendiri diterbitkan dalam fragmen-fragmen yang sulit dibaca dan dipenuhi dengan berbagai penyisipan, dan sering kali tidak menjangkau khalayak pembaca yang lebih luas kecuali jika dilengkapi terjemahan dan analisis tematis. Beberapa teks berbahasa Arab dan Persia misalnya, begitu kompleksnya sehingga, bahkan terjemahan yang baik tetap sulit dipahami, tanpa ada ulasan yang luas yang sayangnya hanya sedikit penerjemah mampu memberikannya. ${ }^{6}$

Konservatisme studi Islam yang sepenuhnya bercorak filologis ini, dikombinasikan dengan Arab/Persia-sentrisme, jelas turut menyebabkan apa yang disebut John Bowen dengan konservatif. ${ }^{7}$ Namun studi Islam telah mengalami

${ }^{1}$ Jalaluddin Rakhmat, Islam aktual: refleksi-sosial seorang cendekiawan Muslim (Bandung: Mizan, 1991); Azyumardi Azra, Islam substantif: agar umat tidak jadi buih (Bandung: Mizan, 2000); Mohammad Sulhan, Islam Realitas Pergulatan Agama, Pendidikan, Menghadapi Perubahan Sosial dan Kompleksitas (Kuningan: Crisis Press, 2013); Mark R. Woodward, "Indonesia, Islam dan Orientalisme: Sebuah Wacana yang Melintas," dalam Jalan Baru Islam Memetakan Paradigma Mutakhir Islam Indonesia (Bandung: Mizan, 1998); Syamsu-1 Arifyn Munawwir, Islam Indonesia di Mata Santri (Pasuruan: Pustaka Sidogiri, 2013); A. Rubaidi, Radikalisme Islam, Nabdlatul Ulama \& masa depan moderatisme Islam di Indonesia (Yogyakarta: Logung Pustaka, 2008); Kamaruddin Amin, Quo Vadis Islamic Studies In Indonesia Current Trends and Future Challenges (Jakarta: DIKTIS UIN Alauddin, 2006).

${ }^{2}$ Musahadi, "Islam Sebagai Sasaran Studi, Identifikasi Awal terhadap Problem, Pola dan Pendekatan Studi Islam di Indonesia," dalam Quo Vadis Islamic Studies In Indonesia Current Trends and Future Challenges (Jakarta: DIKTIS UIN Alauddin Makassar, 2006), 233.

${ }^{3}$ Abdul Djamil, "Studi Islam Indonesia dalam Tradisi Kesarjanaan Belanda," dalam Islam Berbagai Perspektif (Yogyakarta: LPMI, 1995), 47.

"Woodward, "Indonesia, Islam dan Orientalisme: Sebuah Wacana yang Melintas," 48.

5John L. Esposito, Ancaman Islam: mitos atau realitas? (Bandung: Penerbit Mizan, 1994), 203.

"Woodward, "Indonesia, Islam dan Orientalisme: Sebuah Wacana yang Melintas," 49.

7John Richard Bowen, Muslims Through Discourse: Religion and Ritual in Gayo Society (Princeton: Princeton University Press, 1993), 18. 
perubahan mendasar dalam dua dekade terakhir, sedangkan tradisi kesarjanaan filologis terus berlanjut, dengan tingkat konservatismenya yang tinggi, para sarjana yang lebih muda telah memperluas horizon mereka sehingga meliputi pula tema pemahaman dan praktik Islam kontemporer. Mereka sudah bergeliat tidak saja berkiblat ke Haramain (Makkah-Madinah) sebagai pusat dan sumber, tapi juga mulai melirik praktik Islam yang bersinggungan dengan isu-isu perubahan sosial.

Kemunculan studi Islam kawasan dan dialog Islam dengan berbagai konteks dan wilayah yang berbeda dengan kajian sebelumnya, mencerminkan dinamika dan dialog kreatif Islam dengan budaya dan perubahan sosial sangat pesat. Banyak terbit buku terkait isu ini, misalkan "Orientalisme", yaitu, sebagai kritik atas dominasi sarjana Barat atas Kajian Islam di Timur yang tendensius dan pragmatik untuk tujuan politik dan invasi dunia Islam. ${ }^{8}$ Begitu juga kritik atas barat dan upaya balik untuk mengkaji Barat oleh Timur Islam nampak dari buku Hasan Hanafi, Oksidentalisme?.

Meski terkesan utopis karena ketak-berdayaan biaya dan support masyarakat atas proyek ambisius ini, buku-buku terbitan seperti Islam Rasiona $1^{10}$, Islam Realitas, ${ }^{11}$ Islam Aktual, ${ }^{12}$ merupakan ikhtiar menjawab tantangan perubahan sosial masyarakat muslim. Islam dalam konteks hari ini harus melebarkan kajian dan memperluas perhatian pada persoalan aktual, realitas yang perlu dijawab Islam. Persoalan kekerasan atas nama agama, hubungan antar agama yang penuh kecurigaan, demokrasi, hak asasi manusia, perempuan merupakan persoalan yang perlu diberi perhatian oleh Islam sebagai agama rahmatan lil alamin.

Merebaknya kekerasan atas nama agama dan radikalisme yang menggoncang kawasan dan dunia Islam juga memelukan perhatian. Berbagai buku tentang Islam dan radikalisme sebagai konstruksi bagaimana akar masalah, problem dan jawaban Islam atas konflik bermuara agama dan sentimen agama. ${ }^{13}$ Tidak hanya berhenti di sana, kajian emansipatoris dan kewajiban keterlibatan Islam atas praksis pembebasan dapat ditemukan dalam karya Very Verdiansyah berjudul "Islam Emansipatoris. ${ }^{14}$

Respon terkait kekerasan dan konflik agama yang membawa korban jiwa yang besar kemudian menjadi perhatian para pemikir besar Islam dan para sarjana, diantaranya, buku Abdurrahman Wahid, "Islam Tanpa Kekerasan", ${ }^{15}$ dan "Tradisionalisme Radikal" karya Greg Fealy yang menggambarkan dinamika dan kreatifitas studi keislaman dalam merespon dinamika ummat dan perubahan sosial hari ini. ${ }^{16}$ Hasan Hanafi berpendapat bahwa ketika modernisasi memasuki seluruh relung

${ }^{8}$ Edward W. Said, Orientalism (New York: Vintage Books, 1979).

${ }^{9}$ Hassan Hanafi, Okesidentalisme: sikap kita terhadap tradisi Barat (Jakarta: Paramadina, 1999).

${ }^{10}$ Harun Nasution, Islam Rasional: Gagasan dan Pemikiran (Bandung: Penerbit Mizan, 1995).

${ }^{11}$ Sulhan, Islam Realitas Pergulatan Agama, Pendidikan, Menghadapi Perubahan Sosial dan Kompleksitas.

12 Rakhmat, Islam aktual.

${ }^{13}$ Zainuddin Fananie, Atiqa Sabardila, dan Dwi Purnanto, Radikalisme keagamaan \& perubaban sosial (Surakarta: Muhammadiyah University Press, 2002).

${ }^{14}$ Very Verdiansyah, Islam Emansiatoris Menafsir Agama Untuk Praksis Pembebasan (Jakarta: P3M, 2004), 15.

${ }^{15}$ Abdurrahman Wahid, Islam tanpa kekerasan (Yogyakarta: Lkis Pelangi Aksara, 1998).

${ }^{16}$ Greg Fealy, Tradisionalisme Radikal; Persinggungan Nabdlatul Ulama-Negara (Yogyakarta: Lkis Pelangi Aksara, 1997).

Khazanah, Vol. 17 (2), 2019 
kehidupan masyarakat dunia ketiga begitu pesat, maka pada saat itulah mereka kembali mencari identitas diri, kebangsaan, hingga identitas keagamaannya. ${ }^{17}$ Hassan Hanadi hendak mengatakan bahwa sejalan gaya hidup ala Barat yang ditularkan melalui berbagai media telah mencampakkan identitas otentik, oleh sebab itu identitas asli harus direbut kembali.

Di Indonesia wujud perebutan identitas Islam dilakukan dalam banyak cara, diantaranya, upaya memperjuangkan Islam lewat jalur kultural, ${ }^{18}$ yaitu dengan menjadikan umat Islam sebagai civil society yang kuat dan mampu melakukan bargaining position dengan berbagai kelompok kepentingan dan kekuasaan menjadi ummat cerdas dan berdaya. ${ }^{19}$ Di sisi lain, ada yang memilih jalur struktural dengan memenangkan kekuasaan dengan tetap berpegang pada prinsip agama.

Kajian Islam semakin kuat dengan wujud yang bervariasi. ${ }^{20}$ Perebutan identitas Islam, di mana satu pihak menolak semua tradisi di luar Islam, pihak lain justru reaktualisasi progresif atas tradisi ${ }^{21}$ dan bahkan melihat dialog kreatif Islam dengan budaya lokal. Perebutan klaim kebenaran juga berkembang beragam, seperti, gerakan kembali kepada sumber asas Islam yaitu Al Qur'an dan Hadis sebagaimana dikenalkan dan diperjuangkan oleh kelompok Islam fundamental.

Di sisi lain, dengan menekankan pada penggunaan rasionalisme dan humanisme barat untuk reaktualisasi Islam sebagai agama yang harus sesuai zamannya, inilah jalur perjuangan Islam yang disebut belakangan sebagai Islam Rasional atau Islam Liberal. Terakhir, juga terdapat kelompok yang kerap melakukan respon keras dan berupaya terhadap perubahan tatanan sosial dengan cara yang lebih ekstrim yaitu Islam Radikal. ${ }^{22}$

Dalam dinamika yang lain penulis memberi istilah lain yang intinya merupakan semangat beragama, yang lahir untuk bagaimana mendialogkan Islam sehingga memiliki relevansi dengan tuntutan hari ini. Meski ada yang memilih cara tradisional menggunakan hati dan ada yang memilih cara-cara rasional atau modern dan bahkan yang melihat serba relatif seperti yang dipahami pascamodern. ${ }^{23}$

Taufiq mengutip Cassirer yang menyebut manusia hidup di alam semesta yang simbolis. ${ }^{24}$ Bahasa, mitos, kesenian dan agama adalah bagian dari alam semesta, semua

\footnotetext{
${ }^{17}$ Ronald Lukens-Bull, Jihad Pesantren di Mata Antropolog Amerika (Yogyakarta: Gala Media, 2014); Sahal Mahfudh dan Aziz Munawwir, Epistemologi Fiqh Sosial, Konsep Hukum Islam dan Pemberdayaan Masyarakat (Pati: STAIMAFA, 2013).

${ }^{18} \mathrm{Ahmad}$ Suaedy, Islam Indonesia gerakan sosial baru demokratisasi: perspektif pesantren (Jakarta: Wahid Institute, 2009); Ahmad Baso, Islam pascakolonial: perselingkuhan agama, kolonialisme, dan liberalisme (Bandung: Mizan, 2005); Ahmad Syafii Maarif, Membumikan Islam (Yogyakarta: IRCiSoD, 2019).

${ }^{19}$ Merle Calvin Ricklefs dkk., Sejarah Asia Tenggara: dari masa prasejarah sampai kontemporer (Jakarta: Komunitas Bambu, 2013).

${ }^{20}$ Mohammad Abid Al-Jabiri, Agama, Negara, dan Penerapan Syariah (Yogyakarta: Fajar Pustaka Media, 2001). Press, 1997)

${ }^{21}$ Seyyed Hossein Nasr, Traditional Islam in the Modern World (New York: New York University

${ }^{22}$ Sulhan, Islam Realitas Pergulatan Agama, Pendidikan, Menghadapi Perubahan Sosial dan Kompleksitas.

${ }^{23}$ Nasr, Traditional Islam in the Modern World; Maarif, Membumikan Islam.

${ }^{24}$ Taufiq Wildan, Semiotika untuk. Kajian Sastra dan Alquran (Bandung: Yatra Media, 2016), 3. 
ini merupakan benang-benang yang membentuk jaring simbolis, jaring kusut pengalaman manusia. Segenap kemajuan manusia dalam berpikir dan berpengalaman memperhalus serta memperkuat jaringan ini untuk memahami bentuk-bentuk budaya manusia. Segenap kemajuan manusia dalam berpikir dan berpengalaman memperhalus serta memperkuat jaringan ini untuk memahami bentuk-bentuk budaya manusia.

Agama membentuk makhluk simbolis (animal symbolicum), di mana agama dipahami oleh Cliffort Geertz bukanlah entitas yang otonom, tetapi ia terikat dengan konteks, situasi dan zaman yang mengitarinya. ${ }^{25}$ Islam senantiasa tampil searah sosiokultural dimana Islam berada, karenanya Islam tampil dengan ragam wajah yang cenderung berbeda-beda. Islam harus hidup dan terus dihidupkan, dibaca dan diinterpretasikan (diterjemahkan) sesuai konteks sosio-kulturalnya untuk menemukan bentuk idealnya. Tak dapat dipungkiri dialog dan perjumpaan ini akan melahirkan pertarungan, negosiasi dan akomodasi membentuk agama tradisi dan tradisi agama yang berbeda-beda. Inilah Islam Indonesia yang kaya wajah dan menjadi fenomena penting bagi studi hidup manusia.

Sekitar tahun 1960 dan menjelang 1970-an, dinamika kajian Islam semakin meriah dengan munculnya kebijakan Kementerian Agama Republik Indonesia tentang Pendidikan Tinggi Keagamaan membuat kajian keislaman di Indonesia terus bergeliat hingga hari ini. Peneliti tak dapat mengabaikan keberadaan dari Perguruan Tinggi Keagamaan Islam Negeri (PTKIN) yang terus menjelma menjadi institusi Islam yang mengkaji dan lokomotif studi Islam di Indonesia. Saat ini Perguruan Tinggi Keagamaan Islam Negeri (PTKIN) di Indonesia dibawah naungan Kementerian Agama Republik Indonesia ada yang berbentuk universitas (Universitas Islam Negeri), Institut (Institut Agama Islam Negeri) dan Sekolah Tinggi (Sekolah Tinggi Agama Islam Negeri). Data hari ini menggembirakan bahwa terdapat 58 PTKIN yang terdiri atas 17 Universitas Islam Negeri (UIN), 34 Institut Agama Islam Negeri (IAIN), dan 7 Sekolah Tinggi Agama Islam Negeri (STAIN) yang tersebar di seluruh Indonesia. ${ }^{26}$

Universitas Islam Negeri mulai mengembangkan kajian lintas disiplin, bukan saja kajian agama (Religious Studies) yang menjadi kajian akademik di lembaga ini tetapi sudah mulai mengembangkan diri ke wilayah dan kajian umum non-keagamaan dalam hal ini humaniora dan sains, seperti, di UIN Alauddin Makasar, UIN Ar-Raniri Banda Aceh, UIN Maulana Malik Ibrahim Malang, UIN Sunan Gunung Djati Bandung, UIN Sunan Kalijaga Yogyakarta, UIN Syarif Hidayatullah Jakarta, UIN Raden Fatah Palembang, UIN Sultan Syarif Kasim Pekan Baru, UIN Sumatera Utara Medan, UIN Sunan Ampel Surabaya, dan UIN Walisongo Semarang. Kajian Islam bukan saja dilaksanakan di tingkat sarjana bahkan pasca sarjana terutama program Magister dan Doktoral. Hal serupa juga terlihat di IAIN Cirebon, IAIN Serang, IAIN Tulungagung, IAIN Surakarta, STAIN Pekalongan, dan lainnya. Geliat kajian keislaman bergerak terus, berkembang secara kreatif dan dinamis.

Dalam dinamika Perguruan Tinggi Keagamaan Islam Negeri (PTKIN), selain

\footnotetext{
${ }^{25}$ Sulhan, Islam Realitas Pergulatan Agama, Pendidikan, Menghadapi Perubahan Sosial dan Kompleksitas, $2-3$.

${ }^{26}$ https://id.wikipedia.org/wiki/Daftar_perguruan_tinggi_Islam_negeri_di_Indonesia

Khazanah, Vol. 17 (2), 2019 
Sekolah Tinggi Agama Islam (STAI), berkembang pula varian Institut Agama Islam (IAIN) dan kemudian Universitas Islam Negeri (UIN) dengan pengembangan area studi di luar rumpun agama. Dalam konteks perubahan ini terjadi persentuhan dengan beragam tenaga dosen yang berasal dari latar pendidikan umum yang memiliki keragaman pandangan keagamaan. Masalah mendasar yang menjadi fokus penelitian ini terkait bagaimana dinamika wajah keislaman Perguruan Tinggi Keagamaan Islam Negeri (PTKIN) dalam konteks perubahan ke Universitas Islam Negeri terutama dengan masuknya tenaga dosen dari beragam latar belakang pendidikan, disiplin dan keragaman organisasi yang menjadi kekuatan baru di Universitas Islam Negeri (UIN).

Berdasarkan fokus penelitian ini, menarik untuk diteliti terkait pandangan keagamaan dosen UIN yang dibatasi pada para dosen yang mengajar materi keagamaan pada area studi di luar rumpun agama yang terdapat pada tiga Universitas Islam Negeri (UIN), yaitu UIN Ar-Raniry Aceh, UIN Sunan Kalijaga Yogyakarta, dan UIN Sunan Gunung Djati Bandung.

\section{Metode}

Penelitian "Wajah Islam PTKIN" berusaha melihat dinamika dan perubahan Islam di PTKIN. Karenanya penelitian ini menggunakan pendekatan Fenomenologi (Phenomenology Approach) yang berguna untuk menggambarkan keadaan atau fenomena yang terjadi dari realitas di sekitar kehidupan manusia. Melalui metode kualitatif (qualitative method) peneliti akan berusaha mengamati entitas orang dalam lingkungan hidupnya, berinteraksi dengan subjek penelitian, berusaha memahami bahasa dan tafsiran mereka tentang dunia sekitarnya, melihat fenomena di lingkungan penelitan, berusaha memahami dan memberi makna terhadap rangkaian peristiwa yang dilihatnya.

Penelitian ini dilakukan dalam rentang waktu relatif panjang dan berkesinambungan. Pada awal persiapan dan pengamatan awal untuk memperoleh data awal dimulai semenjak Mei 2018 hingga tahap pendalaman yaitu Oktober 2018. Penelitian ini banyak berhubungan dengan pimpinan, peneliti dan dosen secara khusus yang terkait langsung dengan masalah Islam PTKIN, selain itu, penulis juga berhubungan dengan berbagai sumber dan informan. Metode pengumpulan data yang akan dipergunakan dalam penelitian ini adalah observasi, wawancara dan dokumentasi. Analisis data yang akan dipergunakan dalam penelitian ini adalah model analisis data mengalir (flow model). Sejumlah langkah analisis terdapat dalam model ini, yakni reduksi data, penyajian data dan penarikan kesimpulan.

\section{Pembahasan}

\section{Potret Islam dan Pandangan Keagamaan Dosen PTKIN}

Bergesernya Institut Agama Islam Negeri (IAIN) menjadi Universitas Islam Negeri (UIN) meniscayakan berbagai pergeseran, tidak terkecuali bagaimana Islam dipelajari, hidup, dan dikembangkan dalam konteks bermasyarakat, berbangsa, dan bernegara. Untuk mengetahui dampak dari pergeseran tersebut, tentunya dibutuhkan data yang salah satunya didapat melalui angket yang disebar ke dosen-dosen umum di lingkungan UIN Sunan Ar-Raniry Banda Aceh, UIN Sunan Kalijaga Yogyakarta, dan 
UIN Sunan Gunung Djati Bandung yang hasilnya dapat dirinci sebagai berikut: (a) banyak dosen, atau sekitar $44 \%$ sangat setuju bahwa PTKIN menunjang pengembangan Islam yang rahmatan lil alamin dan menyatukan perbedaan agama dan suku bangsa; (b) mayoritas dosen, atau sekitar $71 \%$ sangat setuju bahwa semua prodi di UIN memberikan Mata Kuliah Dasar Umum berisi ilmu dasar keislaman Alquran, Hadits, Fiqh, Sejarah Islam, dan Bahasa Arab; (c) beberapa dosen, atau sekitar 25\% sangat setuju bahwa semua dosen UIN mengikuti upacara bendera setiap hari besar nasional; (d) banyak dosen, atau sekitar 35\% setuju bahwa Islam sebagai landasan hidup dan ideologi negara atau politik; (e) mayoritas dosen, atau sekitar 75\% sangat tidak setuju bahwa hari ini ada kecenderungan munculnya radikalisme agama semisal ISIS, Boko Haram, al-Qaida, dan lainnya, dan itu bukanlah ekspresi keagamaan; (f) mayoritas dosen, atau sekitar 53\% merasa nyaman sebagai umat Islam yang hidup di Indonesia untuk beribadah sesuai syari'at Islam; (g) sebagian dosen, atau sekitar 35\% sangat setuju terkait banyaknya daerah yang memberlakukan perda syari'at; (h) mayoritas dosen, atau sekitar 91\% sangat tidak setuju sekiranya ada orang yang melakukan bom bunuh diri atas nama agama di Indonesia; (i) sebagian besar dosen, atau sekitar 54\% sangat setuju, bahwa Pancasila merupakan ideologi negara alat pemersatu NKRI yang tak bertentangan dengan Islam; (j) sebagian dosen, atau sekitar $36 \%$ kurang setuju sekiranya dosen UIN ada yang aktif dan mendukung ormas terlarang (seperti HTI) dikeluarkan dari UIN; (k) sebagian dosen, atau sekitar 34\% tidak setuju bahwa Partai Nasionalis akhir-akhir ini diklaim bukan partai Islam (partai kafir).

\section{PTKIN Menyongsong Masa Depan: Trend dan Tantangan}

PTKIN/UIN sebagai pusat studi Islam kontemporer dewasa ini sedang dihadapkan dengan berbagai tantangan baru, sebagaimana lembaga dan organisasi yang ada di Indonesia, yang saat ini sedang berhadapan dengan dinamika perubahan sosial, ilmu pengetahuan dan revolusi bidang telekomunikasi yang sangat pesat. Perubahan ini membawa pengaruh dan tantangan yang juga akan menyertai perubahan tersebut, percepatan adalah kata kunci yang akan menentukan eksistensi lembaga dan organisasi menyesuaikan dengan perubahan tersebut.

Dosen Komunikasi UIN Sunan Kalijaga Yogyakarta, Iswandi Syahputra, menuturkan ada beberapa tantangan yang muncul di Perguruan Tinggi pada era disrupsi ini. Di antaranya adalah punahnya ilmu pengetahuan karena munculnya berbagai kecerdasan buatan, masuknya era keberlimpahan ilmu, penerapan teknologi nano menjadi ancaman lain bagi ilmu pengetahuan dan kemanusiaan. ${ }^{27}$ Selain itu tantangan lain yakni regulasi yang ketat dan administrasi yang berbelit serta paradigma positivistik dalam pengelolaan perguruan tinggi. PTKIN/UIN perlu mengantisipasi perubahan ini dengan memberi perhatian dan merekonstruksi ulang terkait beragam

\footnotetext{
${ }^{27}$ Iswandi Syahputra, "Inilah Tantangan Perguruan Tinggi di Era Disrupsi Menurut Dosen Komunikasi UIN Sunan Kalijaga - Tribun Jogja," diakses 19 Desember 2019, https://jogja.tribunnews.com/2018/03/07/inilah-tantangan-perguruan-tinggi-di-era-disrupsimenurut-dosen-komunikasi-uin-sunan-kalijaga.
}

Khazanah, Vol. 17 (2), 2019 
pandangan beragam banyak hal. Tantangan UIN atau PTKIN menurut Prof Yudian Wahyudin, Rektor UIN Sunan Kalijaga Yogyakarta, disertai dengan dorongan kebijakan berupa: (1) Orientasi Kurikulum berbasis Pengetahuan Alam. Saatnya kurikulum pendidikan Islam di Lingkungan PTKIN mengadopsi tuntutan sains yang applied guna menyongsong masyarakat teknologis dan sekaligus kebangkitan applied knowledge yang berbasis eksperimental; (2) Menjadikan Bahasa Arab dan Bahasa Ingris sebagai bahasa sains sekaligus; (3) Penguasaan Bahasa. Bahasa Arab, Inggris, China, Indonesia harus dikuasai seluruh civitas kademik di lingkungan PTKIN/UIN, karena hari ini bahasa itu telah menjadi bahasa teknologi dan bahasa Agama; (4) Merekonstruksi makna bahasa Alquran yang kompatibel dengan tuntutan hari ini. AlAsma dapat dipahami sebagai standar baru, mutu, kualifikasi, terindeks, akreditasi, memahami aturan, undang-undang dan peraturan.

Sementara Sahiron Syamsuddin, Wakil Rektor 2 UIN Sunan Kalijaga Yogyakarta, melihat tantangan PTKIN hari ini adalah: (1) PTKIN/UIN di Indonesia tak jelas rencana induk pengembangan (RIP); (2) Stakebolder PTKIN memiliki dua sisi terkait, satu sisi sebagai ilmuwan, di sisi lainnya sebagai masyarakat; (3) Kajian keislaman, ring analyses atau analisis cincin dan structural analyses berkembang di sastra, Barat; (4) Universal SH tanpa I. Pemahaman keislaman inklusif cenderung tak penting pandang simbol-simbol lahiriyah. Simbol keislaman mengekang umat Islam maju; dan (5) PTKIN dan UIN berani menyongsong Post Doktoral dari luar negeri. PTKIN saatnya menerima Program Post Doktoral dari PTKIN lain, termasuk di dalamnya pembiayaan untuk Post Doktoral Fellow, Ababul Magang Change.

PTKIN juga membutuhkan proses adaptasi perubahan sosialnya. Salah satunya adalah kecepatan dalam inovasi. Kecepatan menjadi barometer menangkap segala peluang dan kebijakan yang antisipatif dan produktif. Jeremi Yoram dan Jeremy Main (1998) dalam, Driving Change How The Best Companies are Preparing for the 21 st Century menyebutkan Its not the big companies that eat the small Its fast that eat the slow yang artinya kecepatan menjadi kata kunci menjawab perubahan. ${ }^{28}$

PTKIN/UIN juga dihadapkan pada selera pasar yang ambisius. Munculnya sosialisme pasar bebas, memungkinkan selera pasar akan memenangkan kompetisi di segala sektor kehidupan. Siapa yang dapat memuaskan kebutuhan pasar di situ ada kemenangan dan kesejahteraan. ${ }^{29}$ PTKIN/UIN saatnya membuka diri dan menyongsong abad baru kebangkitan Asia. Jhon Naisbitt dalam Mega Trends Asia The Eight Asian Megatrends that Are Changing the World melihat renaisans di Asia akan sangat merubah tatanan dan wajah asia yang sangat berbeda dan dramatis. Perubahan tersebut ditandai dengan: ${ }^{30}$ (1) dari dominasi nation state ke jaringan; (2) keutamaan ekspor ke dorongan konsumen; (3) pengaruh Barat ke cara Asia; (4) dari kontrol negara ke dorongan pasar; (5) dari desa ke super cities; (6) dari tenaga kerja kasar ke teknologi tinggi; (7) dari dominasi laki-laki ke perempuan; (8) dari Barat ke Timur akan

${ }^{28}$ Yoram Wind, Driving Change: How the Best Companies Are Preparing for the 21st Century (New York: The Free Press, 1998), 193.

${ }^{29}$ Sulhan, Islam Realitas Pergulatan Agama, Pendidikan, Menghadapi Perubahan Sosial dan Kompleksitas.

${ }^{30}$ John Naisbitt, Megatrends Asia: Eight Asian Megatrends That Are Reshaping Our World (New York: Simon \& Schuster, 1996). 
mempengaruhi cara kerja lembaga dan organisasi publik.

Perubahan di atas memaksa UIN/PTKIN terus mengembangkan jaringan dan mengubah cara kerja dari terlalu tergantung pada negara dengan mengembangkan jaringan, networking dan kemitraan yang saling menguntungkan, baik secara akademik, riset maupun keuangan. Perlu menjadi catatan bahwa orientasi akademik yang tadinya PTKIN banyak berkiblat ke Amerika dan Eropa, kini harus berani melirik Timur, Asia Timur sebagai orientasi baru akademik, karena di Asia Timur telah berkembang budaya baru dan kemajuan terkait applied knowledge.

\section{Peta Pemikiran Islam PTKIN}

\section{UIN Aceh dan Menterjemahkan Syariat dalam Kehidupan}

Menformalkan Islam dan Menghidupkan Syariat

Aceh merupakan daerah istimewa yang memiliki otonomi khusus. Dalam teori hukum, Aceh memiliki lex spesialis, artinya memiliki tempat sederajat dalam peraturan perundangan melalui Qanun menterjemahkan Undang Undang dalam sisi yang dibutuhkan masyarakat. ${ }^{31}$ Karenanya, bicara PTKIN di Aceh berarti berbicara Syariah, Qanun dan kerangka pembentukan hukum Islam. Bicara PTKIN adalah bicara Perda Syariah Aceh. Menurut Dekan Fakultas Syariah UIN Ar-Raniry, Muhammad Siddiq Arnia, Aceh dapat membuat perda sendiri (qanun) yang diberi kewenangan berdasar Undang Undang no 11 tahun 2016 tentang pemerintahan Aceh, terutama bab khusus penerapan hukum Islam Indonesia. ${ }^{32}$

Hambatan pelaksanaan syariah di Aceh menurut Muhammad Siddiq Arnia terjadi di antaranya karena: (1) Tidak terlihat tantangan, yang ada gap jauh antara masyarakat dengan yang ideal. Bagaimana membangun pemahama masyarakat, yang tentunya harus ada ikhtiar terus menerus. Hukum bukan sekedar pemahaman tetapi hukum juga menyangkut pendidikan. Contoh kasus khalwat. Kenapa khalwat dilarang? Banyak yang belum paham akhirnya kena denda. Pendidikan penting untuk memutus jarak dan membangun pemahaman; (2) Ada konteks pidana yang sifatnya adiktif. Khamar, minuman keras, dan judi bersifat adiktif. Hari ini kena, besok kena, orangnya sama lagi. Melanggar, perlu healing, ada gambling. Kasus arak dan judi perlu konseling. Khamar dan judi belum ada upaya penyembuhan, sementara kasus hukumnya adiktif; (3) Agar Qanun maksimal 23 kabupaten/kota diharapkan menjadi perpanjangan tangan provinsi setiap ada produk qanun provinsi.

Kedepan PTKIN di Aceh dalam konteks pengembangan Syariah dan penguatan qanun, yang di antaranya: (1) Perlu ada upaya PTKIN menyiapkan bimbingan dan konseling Islam. Bagaimana menyiapkan healing treatment, bagaimana menyiapkan gambling treatment yang hari ini banyak meliputi persoalan penerapan qanun di Aceh; (2) Mengembangkan dan memperjelas teknis kerjasama. Antara Fakultas Syariah UIN Ar-Raniry, Wilayatul Hisbah [WH], Dinas Syariah Islam, dan MPU (Majelis Permusyawaratan Ulama) atau MUI Aceh. Dengan upaya dan produksi kesepahaman membangun piranti hukum yang lebih manusiawi dan ramah. Aceh salah

\footnotetext{
${ }^{31}$ Emka Alidan, PTKIN di Aceh, 29 Juli 2018.

${ }^{32}$ Muhammad Siddiq Arnia, PTKIN di Aceh, 29 Juli 2018.

Khazanah, Vol. 17 (2), 2019
} 
satu provinsi yang menerapkan Syar'iat Islam. Pranata Islam dan hukum didasarkan pada qanun. Qanun inilah yang menjadi piranti mengatur hubungan masyarakat satu dengan yang lainnya.

UIN Ar Raniry Aceh terlibat secara aktif dalam pembangunan qanun di Aceh. ${ }^{33}$ Penyusunan naskah akademik, drafting sampai penyusunan Undang-undang ke DPRA selalu melibatkan civitas UIN Ar-Raniry, dan alumninya secara aktif menyusun qanun pemerintahan. Misalnya, Qanun pendidikan nomor 11/2014 dan nomor 09/2019 tentang pendidikan, menjelaskan Mata Pelajaran Agama bukan PAI tetapi akhlak, akidah dan sejarah. Produk Qanun Aceh, Jinayah, Qanun Lembaga keuangan syariah (rancangan), Qanun Keluarga, Syiar Islam, dan lainnya. UIN adalah poros peradaban di Aceh. Tokoh dan sekaligus alumni UIN Ar-Raniry yang hari ini banyak membawa gerbong legislasi di DPRA adalah Mahmuddin. Ia adalah Ketua DPR alumni ArRaniry. DPRA ini sangat penting posisinya dalam kaitan legislasi, terutama memproses dan produksi qanun yang dibutuhkan masyarakat. Rancangan qanun dan produk perundangan serta uji publik menakar ketersediaan masyarakat menerima atau menolak diputuskan dalam lembaga legislasi ini, karenanya posisi dan perannya sangat determinan.

Rektor UIN Ar-Raniry, Warul Walidain, adalah ketua Majelis Pendidikan Aceh, di mana dia berperan sebagai center of excellence dan agent think tank untuk mengembangkan kajian dan pengembangan program pendidikan. Tokoh Syariah Aceh adalah Emka Alidan Kepala Dinas Syariah Islam UIN Ar-Raniry juga layak berbangga diri. Salah satu alumninya juga menjabat sebagai kepala Bidang Hukum di Dinas Syariah Aceh, Muzakkir, adalah orang yang paling bertanggung-jawab terkait penyiapan draft Qanun Aceh.

Semua drafting Qanun Aceh dibawa dan diusulkan Gubernur ke DPRA selalu melalui bidang hukum Dinas Syar'iah Aceh ini. Dalam konteks pengembangan Qanun dewasa ini, UIN dan PTKIN paling terdepat dalam riset, mensosialisasikan dan membangun konstruksi hukum yang dapat diterima masyarakat luas baik di Aceh atau luar Aceh. PTKIN atau UIN dan UIN Ar-Raniry secara khusus dalam konteks pengembangan hukum Islam di Aceh paling terdepan sebagai punggawa mengawal keberlakuan hukum Islam di tanah rencong ini. PTKIN sebagai lumbung pengetahuan, spirit dan sumber gagasan yang memperkaya muatan, sumber daya untuk menterjemahkan Islam dalam kehidupan sehari hari. PTKIN menterjemahkan qanun sebagai cara untuk menengahi masalah yang muncul ditengah masyarakat.

\section{UIN Yogyakarta dan Aplikasi Islam}

UIN Sunan Kalijaga atau sering disebut UIN SUKA adalah kampus yang sangat terkenal di Indonesia dengan iklim akademik yang sangat disegani. Berbagai tokoh dunia hadir ke kampus ini untuk merasakan citarasa gudeg pemikiran Islam yang paling maju di Indonesia. Akademisi dunia Johan Hendrik Mauleman, Martin Van Brunissen, William Liadle dari Belanda, sarjana-sarjana Jepang, Mc-Gill, Australia, Ohio sering hadir untuk arisan gagasan dan pemikiran segar terkait Islam Indonesia,

${ }^{33}$ Warul Walidain, PTKIN di Aceh, 2 Agustus 2019. 
Metodologi Studi Islam dan Filsafat serta Sejarah dan Dinamika Islam Kontemporer.

Kampus UIN SUKA sekarang dipimpin oleh seorang rektor yang sangat progresif terus berbenah dan mengembangkan diri, Yudian Wahyudi adalah rektor santri yang sukses melakukan jihad ilmiah dari Tremas ke Harvard. Dalam upaya pengembangan UIN/PTKIN memainkan peran strategisnya terutama setelah menjadi universitas terbuka, UIN Sunan Kalijaga Yogyakarta berusaha menterjemahkan Islam dalam bentuk aplikasi nyata yang terkait dengan kebutuhan dan perkembangan masyarakat yang makin kompleks. Islam bukan saja dipandang sebagai sumber nilai, sumber motivasi hidup, yang membentangkan khazanah ilmu dan pengetahuan yang sangat luas dan dalam, tetapi juga diusahakan untuk diterjemahkan sebagai disiplin yang kontekstual menjawab masalah kekinian.

UIN Sunan Kalijaga sedang menggagas dan mencoba menterjemahkan aplikasi Islam dalam beragam bentuk semisal sosio religio tehnik, applied science, dan supply balal chains yang langsung terkait dengan kondisi nyata kehidupan, yang rinciannya sebagai berikut:

\section{Sosio Religio Tehnik}

UIN Sunan Kalijaga sedang terus mengembangkan kajian disiplin yang kontributif bagi pemecahan masalah sosial. Perkembangan masyarakat yang sangat pesat disertai dengan persoalan baru yang juga komplek. Melihat gejala seperti ini UIN SUKA mencoba membawa setiap program studi yang dikembangkan di kampus ini dapat memberi sumbangan berharga terhadap setiap persoalan yang berkembang di masyarakat. Kampus semestinya hadir terhadap persoalan yang membelit masyarakatnya. Peng-abaian persoalan masyarakat ini akan menyebabkan teralienasinya kampus dari kehidupan sosial. Masyarakat yang menginspirasi berdirinya kampus dan sekaligus laboratorium yang akan menjadi bahan studi di universitas. Matematika teknik merupakan bagian tak terpisahkan dalam menterjemahkan dan mengaplikasikan disiplin untuk menjawab problematika yang berkembang hari ini.

Konteks keislaman UIN Sunan Kalijaga menjadi solusi di masyarakat. Masalah sosial terkini yang hari ini menjadi perhatian dan membawa dampak merusak di masyarakat di antaranya: (1) Hoaks. Konsen Jurusan Sains UIN Yogyakarta untuk menjawab problem medsos akut di antaranya Hoaks atau kabar bohong yang dihembuskan untuk tujuan tertentu merupakan masalah krusial yang merusak sendisendi keagamaan, kebangsaan, dan kemasyarakatan; (2) Pencurian data chip. Problem akut dan berbahaya adalah pencurian data chip untuk penyimpangan kegunaan. Semakin canggih teknologi perbankan, maka makin canggih pula modus operandi kejahatan di perbankan tersebut; (3) Peretas. Pencurian data atau rahasia untuk beragam kepentingan. Peretas (hacker) adalah orang yang mempelajari, menganalisis, memodifikasi, menerobos masuk ke dalam komputer dan jaringan komputer, baik untuk keuntungan atau dimotivasi oleh tantangan.

\section{Applied Science Islam: Integrasi Metafisika dan Fisika}

UIN Sunan Kalijaga Yogyakarta berusaha membuat sintesa menarik terkait pengembangan sains yang berbasis integrasi metafisika dan fisika. Menurut Prof. 
Yudian Wahyudi mutu pendidikan Islam babak belur. ${ }^{34}$ Kenapa umat islam mundur, dan mengapa? Menurutnya, pertama, karena umat Islam menyimpang dari Alquran dan Hadist. Padahal Islam jelas, alam nasyrah laka shadrak (tidakkah aku lapangkan dadamu Muhammad), fal ya'budu rabba bazda al-bait (maka sembahlah Tuhan yang menciptakan rumah ini atau ka'bah); Kedua, konflik internal; Ketiga, kenapa mundur, karena umat Islam membuang experimental sciences.

UIN/PTKIN berusaha menemukan kembali semangat Ibnu Sina yang hilang dalam sejarah. Dalam sebuah tulisan yang dipublikasikan Republika (2018) KH Yudian Wahyudi, Rektor UIN Sunan Kalijaga, yang sekaligus juga President of Asian Islamic Universities Association memberi alternatif baru sebagai upaya mempersatukan dan mengintegrasikan ilmu pengetahuan. Kelemahan UIN/PTKIN, di antaranya karena belum menemukan definisi Islam yang sejalan dengan integrasi agama dan sains ini. UIN/PTKIN belum menemukan hukum terbesar yang mengatur sejarah (dunia fisik) ini. Padahal hukum terbesar yang mengatur kehidupan duniawi menurut Alquran hanyalah taqdir; hukum positif (manfaat, maslahat, rahmat, baik, untung, kanan) dan negatif (mafsadah, laknat, mudharat, buruk rupa, rugi, kiri) sekaligus pada benda atau makhluk Allah. Tentunya, tidak ada positif tanpa negatif sekaligus. Inilah yang disebut sunnatullah yang tidak akan pernah berubah. Itulah hukum alam itu.

Dengan memperhatikan lapis-lapis keilmuan di atas, langkah yang ditempuh untuk menemukan kembali Ibnu Sina adalah kembali ke Filsafat. Dalam pengertian mempersatukan kembali rumpun keilmuan metafisika (ilmu keagamaan Islam, seperti Fikih dan Tafsir) dengan rumpun keilmuan fisika (natural, eksperimental dan applied Knowledge) dengan dilandasi kemampuan bahasa Arab. Ini karena fondasi Ilmu pengetahan minimal menurut Yudian Wahyudi adalah Matematika sebagai fondasi fisika, dan bahasa untuk mengakses berbagai sumber pengetahuan.

\section{Supply Halal Chains}

Dekan Saintek UIN Sunan Kalijaga, Murtono, menyebutkan, Saintek yang dikembangkan di UIN SUKA tidak sekedar pendidikan umum tetapi ada motif profetis..$^{35}$ Di mana saintek UIN SUKA menjamin dan mengembangkan industri etis yang menjamin kerahmatan dan keselamatan konsumen. Program Studi Saintek memperkenalkan Supply Halal Chains, sebuah ikhtiar memastikan jaringan dan rantai produksi sampai ke konsumen dijamin kehalalannya. Program ini berusaha memastikan kepada konsumen bahwa setiap produk barang yang beredar di masyarakat itu halal dari sisi barang, halal dari sisi proses dan halal dari sisi produk. Supply Halal Chains UIN Sunan Kalijaga Yogyakarta secara umum terkait dengan pengembangan fungsi jurusan yang ikut bertanggung jawab atas berlakunya hal hal sebagai berikut: (1) Memastikan barang atau produk terbuat dari barang yang halal. Kehalalan sebuah produk berawal dari zat atau bahan yang halal dan bersih serta suci. Sains UIN Yogyakarta berusaha melihat wilayah ini sebagai bentuk pengabdian masyarakat yang sangat urgen dalam menjamin kehalalan sebuah produk yang ada di

\footnotetext{
${ }^{34}$ Wahyudi, Tantangan PTKIN.

${ }^{35}$ Murtono, PTKIN di Yogyakarta, 11 Juli 2018.
} 
masyarakat; (2) Memastikan proses produksi menggunakan cara-cara baik. Selain bahan, proses produksi-pun diharapkan juga menggunakan cara-cara yang halal, yang sesuai dengan kaidah-kaidah yang dibenarkan oleh agama dan hukum yang berlaku di Indonesia; dan (3) Produk dijamin kehalalan. Sampai menjadi barang jadi, produk yang siap diedarkan di masyarakat juga dipastikan memperoleh jaminan kehalalan. Baik dari sisi kemasan, barang, bahan dan jaminan kesehatan yang dapat dipertanggung jawabkan secara medis maupun akademis.

\section{UIN Bandung dan Mengemas Islam \\ Sinta Award dan Budaya Tulis di UIN SGD Bandung}

Penghargaan Sinta Awards dapat menumbuhkan budaya tulis bagi para civitas UIN SGD Bandung, namun budaya tulis juga perlu didukung dengan penghargaanpenghargaan yang perlu diberikan kepada civitas dosen yang tidak hanya memiliki banyak karya tetapi juga seberapa besar karya tersebut memberikan sumbangsih bagi kehidupan masyarakat Indonesia. Terbukti pada tanggal 4 Juli 2018, UIN Sunan Gunung Djati Bandung berhasil meraih Science and Technology Index (Sinta) Awards tahun 2018 sebagai Institusi dengan produktivitas publikasi tertinggi dalam kategori Perguruan Tinggi Keagamaan dari Kementerian, Riset, Teknologi, dan Pendidikan Tinggi (Kemenristek Dikti). Selain itu, penghargaan yang diterima oleh salah satu dosennya Muhammad Ali Ramdhani sebagai penulis artikel ilmiah dengan skor tertinggi kategori Perguruan Tinggi Keagamaan.

Penghargaan Sinta Awards sebagai ajang yang positif untuk motivasi peningkatan publikasi ilmiah dan merupakan prestasi gemilang sivitas akademisi UIN SGD Bandung dalam produktivitas publikasi ilmiah sejalan dengan kebijakan dan pembinaan struktur Kementerian Agama RI.

\section{Rumah Quran dan Ulama Zaman Now}

UIN sebagai lembaga Pendidikan Tinggi Islam harus mampu mengembalikan arah baru Islam kepada substansi dan esensi dari Islam itu sendiri yang hakikatnya adalah selamat dan menyelamatkan dalam kedamaian. Dalam konteks ini, UIN harus mampu menghasilkan lulusan yang memahami hakikat Islam dan mengimplementasikan dalam setiap aspek kehidupan manusia yang senantiasa berubah dan penuh tantangan globalisasi. Lulusan yang dihasilkan harus mampu memadukan dua sumber ilmu quraniyah dan kauniyah sebagai ulama zaman now yang mampu mempromosikan nilai-nilai Islam secara umum, dan arah baru peta Islam sebagai rahmatan lil alamin. Kaderisasi ulama zaman now menjadi bagian penting dari upaya bagaimana memastikan kaderisasi ulama berjalan dengan optimal dalam pendidikan di rumah Quran UIN SGD Bandung.

Implementasi rumah Quran ini diwujudkan dalam lembaga tahfizh Quran di setiap fakultas yang bertujuan menyisir setiap mahasiswa yang belum mampu membaca dan menghafal Quran. Rumah Quran UIN SGD Bandung merupakan wadah bagi para mahasiswa penghafal Quran untuk mewujudukan ulama zaman now yang dibutuhkan oleh masyarakat milenial. Mahasiswa para penghafal Quran dari UIN SGD Bandung telah memperoleh prestasi atas nama Mohammad Rifat Albanna, Juara I Musabaqah 
Hifzhil Quran (MHQ) Putra 30 Juz, Ibrahim Abdul Jabar Juara I Musabaqah Hifzhil Quran (MHQ) Putra 10 Juz, Ulfiyaturrohmah Juara Harapan I Musabaqah Hifzhil Quran (MHQ) Putri 30 Juz, Ro'yu Nahriyah Juara 3 Musabaqah Hifzhil Quran (MHQ) Putri 10 Juz pada musabaqah tingkat nasional di event Invitasi Pekan Pengembangan Bakat dan Minat Mahasiswa (IPPBMM) VII Perguruan Tinggi Keagamaan Negeri (PTKIN) VII di IAIN Purwokerto, 24-27 April 2018 Purwokerto.

Menghasilkan seorang kyai zaman now bagi perguruan tinggi Islam UIN SGD Bandung harus belajar banyak dari Universitas Al-Azhar yang telah menghasilkan ribuan ulama dengan kemampuan ilmu yang tinggi, pengalaman dan wawasan tentang dunia internasional yang luas dan kemampuan-kemampuan lain. Ada tiga hal yang terlihat UIN SGD Bandung belajar banyak dari Universitas Islam ternama di dunia ini, yaitu, pertama, UIN SGD Bandung memprioritaskan mahasiswa para penghafal Quran untuk terus ditingkatkan kemampuan dan keilmuannya; Kedua, penguatan terhadap budaya lokal, nasional dan internasional, kyai zaman now yang dihasilkan oleh UIN SGD Bandung dapat lebih kuat memahami budaya lokal dan nasional seperti Islam nusantara yang sangat kental dan melekat dalam tradisi budaya lokal masyarakat muslim indonesia. Kemampuan inilah yang menjadi keunggulan kyai zaman now yang dihasilkan oleh UIN SGD Bandung; Ketiga, penguatan terhadap kemampuan teknologi yang terus berkembang.

Semua sumber-sumber naskah agama dari para ulama salaf sampai ulama modern telah terangkum dalam teknologi sehingga diharapkan kyai zaman now yang diluluskan oleh UIN SGD Bandung mampu beradaptasi terhadap setiap perkembangan teknologi bahkan ulama yang teknorat dan teknorat yang ulama. Menghasilkan kyai zaman now yang digagas UIN SGD Bandung merupakan sebuah upaya terstruktur dan berjenjang untuk memastikan upaya kaderisasi ulama ini dapat berjalan dengan maksimal.

Konsep kerjasama dalam membentuk, mengkader dan menghasilkan kyai atau ulama yang memahami ilmu agama dan melek dengan perkembangan zaman dan teknologi diupayakan dengan cara bekerja sama dengan pemerintahan daerah di wilayah Jawa Barat dan memberikan biaya kepada anak-anak tidak mampu dan bersemangat untuk kuliah dan belajar agama. Mahmud melihat banyak anak yang ingin kuliah tetapi tidak mampu dan akhirnya hanya masuk pesantren. Pada siang hari mereka kuliah di UIN Bandung dan malamnya kembali ke pesantren untuk mondok menimba dan memperdalam ilmu-ilmu keislaman," kata Mahmud. ${ }^{36}$ Rumah Quran yang disiapkan sebagai sarana untuk para penghafal Quran yang mencetak kyai zaman now terletak dikampus III seluas 3 hektar. Menurut Mahmud program ini merupakan hasil kerjasama UIN Bandung dengan Pemprov Jawa Barat, serta Bupati dan Walikota Bandung. Saat ini, sedang dalam proses pembangunan yang dibantu oleh Pemprov Jabar. Pengembangan inovasi dalam pendidikan agama ini didukung oleh Menteri Agama RI Lukman Hakim karena itu menjadi ciri Perguruan Tinggi Keagamaan Islam (PTKI).

Dalam sejarah peradaban Islam, ulama sering muncul sebagai pemimpin

36Mahmud, Sidang Senat Terbuka Dies Natalis ke-50 UIN Sunan Gunung Djati, 10 April 2018. 
gerakan pembaharuan sosial dan politik. Kecenderungan ulama menampakkan kehadirannya dalam tiap kritis politik dan sosial di negara-negara Islam tidak lepas dari dua alasan, yaitu: pertama, adanya kenyataan bahwa ulama secara historis menganggap dirinya sebagai titik tolak kesadaran moral Islam; Kedua, kenyataan bahwa ulama mengabdi pada lembaga masjid dan madrasah tempat jamaah mereka berkumpul secara teratur. Di situ juga ulama berkumpul untuk membicarakan berbagai masalah yang berkaitan dengan masyarakat, umat dan keimanan. ${ }^{37}$

\section{Madrasah Husnul Khatimah}

Program unggulan UIN SGD Bandung adalah membangun pendidikan yang sasarannya adalah manusia super dewasa (lansia) yaitu pendidikan untuk lansia yang bertujuan untuk membimbing mereka dalam meraih husnul khatimah maka disebut dengan madrasah husnul khatimah. Menurut Mahmud, latar belakang program unggulan ini adalah untuk mengurus dan berbakti sepenuh hati kepada orang tua sama nilainya dengan berjihad ke medan perang. ${ }^{38}$ Orang tua kita itu manusia istimewa dan terbaik. Jika orang tua itu sanggup mengurus 10 anaknya, 10 anak belum tentu sanggup dan mampu mengurus keduanya. Kesibukan bekerja dan berkarier terkadang menjadi alasan banyaknya anak yang tidak sanggup mengurus mereka. Dengan demikian Madrasah Husnul Khatimah (MHK) diperlukan dalam mempersiapkan masa depan orang tua dengan penuh perhatian, kasih sayang, dan saat ajal tiba, meraih husnul khatimah. Menciptakan lingkungan dan suasana yang religius dan menyenangkan bagi orang tua. Jika tidak sempat dilakukan sendiri, carilah jasa orang lain untuk menemani orang tua kita.

Zaman globalisasi merupakan tantangan besar bagi pendidikan Islam yang berfokus pada kemaslahatan dunia dan akhirat, para pemuda tentunya memiliki konsep yang sering menyesatkan dengan konsep 'muda berfoya-foya, tua kaya raya, dan mati masuk surga. Di mana masa muda mereka, apa yang telah mereka lakukan untuk masa tua mereka, dan apa yang sudah disiapkan untuk bekal di akhirat mereka. Mereka masih muda hanya ingin menikmati kekayaan orangtuanya, hidup dengan bergelimang harta dan kekayaan, dan ketika mati pun ingin masuk surga.

Program Madrasah Husnul Khatimah yang digagas oleh UIN SGD Bandung merupakan program yang tidak hanya menyadarkan manusia bahwa kebahagiaan hidup hanya untuk dunia tetapi juga kebahagiaan yang jauh lebih penting yaitu kebahagiaan akhirat. Karena itu program yang digagas oleh UIN SGD Bandung harus sejalan dengan prinsip-prinsip yang telah ditanamkan oleh Rasulullah untuk meraih husnul khatimah, di antaranya adalah doa yang selalu dibaca di penghujung sujud ketika shalat yaitu 'allabuma inni asaluka husnul khatimah' (Ya Allah hamba memohon untuk memperoleh husnul khatimah).

Demikianlah program Madrasah Husnul Khatimah yang menjadi cikal

${ }^{37}$ Hiroko Horikoshi, Kyai dan perubaban sosial (Jakarta: Perhimpunan Pengembangan Pesantren dan Masyarakat (P3M), 1987), 36.

${ }^{38}$ Mahmud, "Madrasah Husnul Khatimah - UIN SUNAN GUNUNG DJATI BANDUNG," diakses 19 Desember 2019, https://uinsgd.ac.id/kolom/madrasah-husnul-khatimah/.

Khazanah, Vol. 17 (2), 2019 
Hasbiyallah, Moh. Sulhan, Heri Khoiruddin \& Undang Burhanudin

kemajuan dan peradaban umat untuk membimbing di akhir kehidupan manusia meraih kebahagiaan sejati yakni surga Allah Swt. Sebab lembaga-lembaga pendidikan yang berfokus pada usia dini telah banyak didirikan dan Madrasah Husnul Khatimah menjadi madrasah pertama yang berfokus pada manusia usia lanjut (senja).

\section{Simpulan}

Didasarkan pada uraian di atas, penelusuran terkait Wajah Islam PTKIN, khususnya di Universitas Islam Negeri (UIN) Ar-Raniry Aceh, UIN Sunan Kalijaga Yogyakarta, dan UIN Sunan Gunung Djati Bandung tentang potret Islam dan pandangan keagamaan menunjukkan bahwa PTKIN menunjang pengembangan Islam yang rahmatan lil'alamin dan menyatukan perbedaan agama dan suku bangsa. Menterjemahkan Islam rahmatan lil 'alamin adalah tantangan tersendiri bagi PTKIN khususnya UIN, didasarkan pada tantangan ini, beberapa kebijakan dapat ditempuh, misalnya orientasi kurikulum haruslah berbasis pengetahuan alam, menjadikan Bahasa Arab dan Bahasa Ingris sebagai bahasa sains sekaligus, merekonstruksi makna bahasa Alquran yang kompatibel dengan tuntutan zaman, dan pemberian gelar akademik yang bersifat inklusif. Masing-masing Universitas Islam Negeri (UIN) memiliki fokus dan kekhususan tersendiri untuk tampil dan berkontribusi mengembangkan Islam rahmatan lil'alamin, contohnya UIN Aceh berupaya untuk menjadi lokomotif penggerak syariah Islam, UIN Yogyakarta mengembangkan sosio religio tekhnik, dan UIN Bandung dianugerahi Sinta Award dan terus mengembangkan budaya.

\section{Daftar Pustaka}

Amin, Kamaruddin. Quo Vadis Islamic Studies In Indonesia Current Trends and Future Challenges. Jakarta: DIKTIS UIN Alauddin, 2006.

Azra, Azyumardi. Islam substantif: agar umat tidak jadi buih. Bandung: Mizan, 2000.

Baso, Ahmad. Islam pascakolonial: perselingkuhan agama, kolonialisme, dan liberalisme. Bandung: Mizan, 2005.

Bowen, John Richard. Muslims Through Discourse: Religion and Ritual in Gayo Society. Princeton: Princeton University Press, 1993.

Djamil, Abdul. "Studi Islam Indonesia dalam Tradisi Kesarjanaan Belanda." dalam Islam Berbagai Perspektif. Yogyakarta: LPMI, 1995.

Esposito, John L. Ancaman Islam: mitos atau realitas? Bandung: Penerbit Mizan, 1994.

Fananie, Zainuddin, Atiqa Sabardila, dan Dwi Purnanto. Radikalisme keagamaan \& perubahan sosial. Surakarta: Muhammadiyah University Press, 2002.

Fealy, Greg. Tradisionalisme Radikal; Persinggungan Nahdlatul Ulama-Negara. Yogyakarta: Lkis Pelangi Aksara, 1997.

Hanafi, Hassan. Oksidentalisme: sikap kita terbadap tradisi Barat. Jakarta: Paramadina, 1999.

Horikoshi, Hiroko. Kyai dan perubahan sosial. Jakarta: Perhimpunan Pengembangan Pesantren dan Masyarakat (P3M), 1987.

Al-Jabiri, Mohammad Abid. Agama, Negara, dan Penerapan Syariah. Yogyakarta: Fajar Pustaka Media, 2001. 
Lukens-Bull, Ronald. Jihad Pesantren di Mata Antropolog Amerika. Yogyakarta: Gala Media, 2014.

Maarif, Ahmad Syafii. Membumikan Islam. Yogyakarta: IRCiSoD, 2019.

Mahfudh, Sahal, dan Aziz Munawwir. Epistemologi Fiqh Sosial, Konsep Hukum Islam dan Pemberdayaan Masyarakat. Pati: STAIMAFA, 2013.

Munawwir, Syamsul Arifin. Islam Indonesia di Mata Santri. Pasuruan: Pustaka Sidogiri, 2013.

Musahadi. "Islam Sebagai Sasaran Studi, Identifikasi Awal terhadap Problem, Pola dan Pendekatan Studi Islam di Indonesia." Dalam Quo Vadis Islamic Studies In Indonesia Current Trends and Future Challenges. Jakarta: DIKTIS UIN Alauddin Makassar, 2006.

Naisbitt, John. Megatrends Asia: Eight Asian Megatrends That Are Reshaping Our World. New York: Simon \& Schuster, 1996.

Nasr, Seyyed Hossein. Traditional Islam in the Modern World. New York: New York University Press, 1997.

Nasution, Harun. Islam Rasional: Gagasan dan Pemikiran. Bandung: Penerbit Mizan, 1995. Rakhmat, Jalaluddin. Islam aktual: refleksi-sosial seorang cendekiawan Muslim. Bandung: Mizan, 1991.

Ricklefs, Merle Calvin, Bruce McFarland Lockhart, Albert Lau, Portia Reyes, dan Maitrii Aung-Thwin. Sejarah Asia Tenggara: dari masa prasejarah sampai kontemporer. Jakarta: Komunitas Bambu, 2013.

Rubaidi, A. Radikalisme Islam, Nabdlatul Ulama \& masa depan moderatisme Islam di Indonesia. Yogyakarta: Logung Pustaka, 2008.

Said, Edward W. Orientalism. New York: Vintage Books, 1979.

Suaedy, Ahmad. Islam Indonesia gerakan sosial baru demokratisasi: perspektif pesantren. Jakarta: Wahid Institute, 2009.

Sulhan, Mohammad. Islam Realitas Pergulatan Agama, Pendidikan, Menghadapi Perubahan Sosial dan Kompleesitas. Kuningan: Crisis Press, 2013.

Syahputra, Iswandi. "Inilah Tantangan Perguruan Tinggi di Era Disrupsi Menurut Dosen Komunikasi UIN Sunan Kalijaga - Tribun Jogja.” Diakses 19 Desember 2019. https://jogja.tribunnews.com/2018/03/07/inilah-tantanganperguruan-tinggi-di-era-disrupsi-menurut-dosen-komunikasi-uin-sunankalijaga.

Verdiansyah, Very. Islam Emansiatoris Menafsir Agama Untuk Praksis Pembebasan. Jakarta: P3M, 2004.

Wahid, Abdurrahman. Islam tanpa kekerasan. Yogyakarta: Lkis Pelangi Aksara, 1998.

Wildan, Taufiq. Semiotika untuk Kajian Sastra dan Alquran. Bandung: Yatra Media, 2016.

Wind, Yoram. Driving Change: How the Best Companies Are Preparing for the 21st Century. New York: The Free Press, 1998.

Woodward, Mark R. "Indonesia, Islam dan Orientalisme: Sebuah Wacana yang Melintas." Dalam Jalan Baru Islam Memetakan Paradigma Mutakhir Islam Indonesia. Bandung: Mizan, 1998. 
Hasbiyallah, Moh. Sulhan, Heri Khoiruddin \& Undang Burhanudin 